\title{
Health, economy and social capital in Nordic children aged 13-17 years and their families: changes between 1984, 1996 and 2011
}

\author{
Leeni T Berntsson ${ }^{* 1}$, Karin C Ringsberg ${ }^{2}$, Bo Eriksson ${ }^{3}$, Lennart Köhler ${ }^{1,2}$ \\ ${ }^{1}$ Nordic School of Public Health, Sweden \\ ${ }^{2}$ Sahlgrenska Academy, Institute of Health and Care Sciences, Gothenburg University, Gothenburg, Sweden \\ ${ }^{3}$ Sahlgrenska Academy, Centre for Health Metrics, Gothenburg University, Gothenburg, Sweden
}

Received: June 30, 2015

DOI: $10.5430 /$ ijh.v2n1p51
Accepted: October 11, $2015 \quad$ Online Published: November 16, 2015

URL: http://dx.doi.org/10.5430/ijh.v2n1p51

\begin{abstract}
Background: Three repeated cross-sectional surveys, using representative samples of children, aged 2-17 years, stratified for age and sex, were conducted in each of the five Nordic countries (Denmark, Finland, Iceland, Norway and Sweden) in 1984, 1996 and 2011. The aim of the present study was to analyze how the health of Nordic 13-17 years old children developed over time, using results from the three surveys in relation to changes in economy and social capital.

Methods: Data from 2,905 children in 1984, 2,922 in 1996 and 2,257 in 2011 were collected using mailed questionnaires. Indicators in three areas were used. The Health indicator was taken as absence of psychosomatic complaints. Economy was represented by social class, housing and disposable income. Social capital contained absence of bullying, the child's organized group activities, parents playing with their children, and parents' position of trust. Three composite indices one for each area were formed and called Health, Economy and Social Capital Index.

Results: There were statistically significant increases of psychosomatic health complaints for children 13-17 years in all the Nordic countries, strongest among girls, at the same time as the economy and social capital of the families increased, particularly in the first period (1984-1996).

Conclusions: In spite of the families' growing economy and improved standard of living there is an increasingly harsh climate in society, with stress, dissatisfaction, bullying and mental health problems. It supports conclusions from other studies that only economic growth is not enough for the full wellbeing of the population. It also supports the importance of the social cohesion, affiliation and solidarity, advanced and reinforced by equitable distribution of the wealth. Social cohesion is important for schooling, on the values of self help, equity, to seek solutions for health among youths.
\end{abstract}

Key Words: Adolescent health, Child health, Repeated cross-sectional surveys, Family economy, Social capital, Nordic countries

\section{INTRODUCTION}

In 1984, 1996 and 2011, three cross-sectional studies of children's health and well-being (The NordChild study) were carried out in the five Nordic countries (Denmark, Finland,
Iceland, Norway and Sweden). The study groups were selected as representative samples of children aged 2-17 years, stratified for sex and age. The results from the NordChild study have been widely published in scientific journals, as Sweden.

Published by Sciedu Press 
summary reports and as doctoral theses. ${ }^{[1-9]}$

The general results from these studies confirmed the good health, the high living standard and the excellent prerequisites for a proper quality of life among Nordic children. ${ }^{[3,5,10,11]}$ However, the results also showed an increase of long term illness (LTI) in children aged 2-17 years from $7.9 \%$ in 1984 to $14.6 \%$ in $1996^{[6]}$ and to $17.8 \%$ in 2011. ${ }^{[8]}$ Psychosomatic complaints (PSC) increased among the Nordic children, from $17.1 \%$ in 1984 to $24.2 \%$ in $1996^{[4]}$ and to 26.2 in 2011. ${ }^{[8]}$ Thus, LTI and PSC almost doubled between the surveys in 1984 and in 1996, while the increase from 1996 to 2011 was more modest. The increase was greatest in the age group 13-17 years. At the same time, the families' economy improved substantially, implying a health paradox: improved material resources but a worsened health situation. Between 1984 and 1996, there was also a statistically significant positive association between the health indicator and the social capital indicators but a negative association with two of the economic indicators. ${ }^{[7]}$ As the PSC have increased consistently since 1984 , still being quite high in 2011 in the oldest age-group, 13-17 years, ${ }^{[8]}$ it seemed urgent to analyze the new data of particularly that age group, in order to see if the paradox observed above remained, and to relate it to the development of the social capital.

The basis for the study of social capital consists of two theories: 1) Coleman's theory on Human Capital, ${ }^{[12]}$ which suggests that the origin of health is formed by social relations and group membership, both structural and interpersonal; and 2) Putnam's theory on Social Capital, ${ }^{[13]}$ which states that networks, norms and social trust facilitate co-operation for mutual benefit and in turn lead to a broader social cohesion.

Several authors highlight the connection between child health and determinants, such as social capital. ${ }^{[14-21]}$ There are studies of socioeconomic differences and health ${ }^{[22,23]}$ as well as cultural differences and health. ${ }^{[24,25]}$ Family income is a key determinant of health child development, reducing the children's likelihood of incurring certain illnesses and cushioning the consequences of ill-health. ${ }^{[21,23]}$

Evidence also shows that social trust and social support are associated with life satisfaction globally and that the correlation is stronger in high-income countries, particularly for Northern Europe, than for less developed societies. ${ }^{[26]}$ Abel $\&$ Frohlich $^{[27]}$ suggested Amartua Sen's capability approach as a useful link between capital interaction theory and action to reduce social inequalities in health. They suggested that people's capabilities to be active for their health should be considered as a key concept in public health practice to reduce health inequalities.

The aim of the present study was to analyze how the health of Nordic 13-17 years old children developed over time, using results from surveys in 1984, 1996 and 2011 in relation to changes in economy and social capital.

\section{MATERIAL AND METHODS}

The NordChild study consists of a series of repeated crosssectional surveys of children aged 2-17 years in the five Nordic countries. In each country random samples of about 3,000 children aged 2-17 years stratified for age and sex were drawn from the population registers of the respective National Bureau of Statistics. Three rounds of surveys were conducted in 1984, 1996 and 2011. The survey design was throughout attempted to be the same. The total population included 10,213 individuals in 1984, 10,317 in 1996 and 7,715 in 2011 . The response rate was $67 \%$ in $1984,70 \%$ in 1996 and $48.2 \%$ in 2011.

The present article focuses on children who are 13-17 years old. This sample was also made by the respective National Bureau of Statistics. The number of participants among 1317 year olds in all countries together were 2,905 individuals in 1984, 2,992 in 1996 and 2,257 in 2011. The response rates for boys and girls were about the same. The partial nonresponse i.e. missing answers to certain questions was rather small for the outcome variables. The highest percentage was $3 \%$.

\subsection{Data collection}

Data were collected using mailed questionnaires with the same basic questions in 1984, 1996 and 2011. In 1996 three questions were added concerning DVD watching, playing video or computer games as well as going to concerts; and in 2011, questions about the use of social media on the Internet were added. The questionnaire was translated into the first language of each country. It included questions about the child and the family, the health of the child, the contacts with health care, the child's own activities and activities together with the parents, socioeconomic factors and the parents' health and well-being. The questionnaires have been used in large population studies ${ }^{[1,3]}$ and studies of children with chronic illness. ${ }^{[10]}$ The parent most familiar with the child's situation was instructed to fill in the answers together with his or her partner and, if possible, together with the child.

\subsection{Outcome variables, indicators and indices 2.2.1 Health}

The percentage of children without PSC was chosen as an indicator of a good health status, as PSC can be regarded 
as a sensitive indicator of stress-related health. ${ }^{[3,28-30]}$ The PSC indicator was constructed using six questionnaire variables: stomach complaints, headaches, sleeplessness, dizziness, backache and loss of appetite. The respondents were instructed to insert a cross only if the complaints occurred every week or every other week.

\subsubsection{Economy}

Three indicators were used to describe the economic situation for groups of families: the parents' occupational class, their disposable income level and the housing standard.

The occupational class of the parents was determined according to the Swedish socio-economic classification ${ }^{[31]}$ and divided into seven groups based on the parent with the highest occupational class: 1) employed and self-employed professionals, higher civil servants and executives; 2) intermediate non-manual employees; 3 ) assistant non-manual employees; 4) skilled workers; 5) unskilled workers; 6) farmers and selfemployed (other than professionals); and 7) students. The percentage of children with families belonging to a middle or upper social class (classes 1-3 above) was used as an indicator of high occupational standard.

Disposable income was measured as the family's monthly income after taxes. Income comprised salaries, income from the family's own firm/farm, pension, benefits and allowances. The disposable incomes were classified into six brackets. The percentage of children with families with income in the two highest brackets was designated as an indicator of high family income status. The housing standard was divided into two groups: 1) apartment in a multifamily dwelling and 2) detached or town house. The percentage of respondents living in a detached or town house was taken to be an indicator of housing standard.

\subsubsection{Social capital}

Four indicators were used to describe social capital in the study and defined as the percentage of the following variables: 1) Experience of bullying was assessed by answers (often, sometimes, seldom, never) to the question: "Has the child been bullied?" The positive outcome was the "seldom or never" answer. 2) The child's group activity was measured by answers (never, one or more times a year, a month, a week) to the question: "Does the child participate actively in organizations?" "Once a week or more" were positive outcomes. 3) Parents' playing with their children was measured by answers (never, one or more times a year, a month, a week) to the question: "How often do you, spouse or partner and the child play, play games together?" The positive outcome was the "once a week or more" answers. 4) Parents" position of trust in an organization was measured by answers (no or yes) to the question: "Have you held a position of trust in an association or organization in the last few years?" Reporting a position was considered a positive outcome.

\subsubsection{Composite index}

Using the eight indicators above, three indices were defined: 1) The Health Index was simply taken to be the percentage of positive outcome for the health indicator itself. 2) The Economic Index was defined as a mean of the percentages of the three indicators defined above. 3) The Social Capital Index was defined as a mean of the percentages of the four indicators defined above.

\subsection{Ethical approval}

Ethical approval was obtained in Finland, Iceland and Sweden. Denmark and Norway do not require approval for this kind of studies but their Data Inspection Authorities were informed. The respective National Bureau of Statistics in each country did the sampling. In a missive attached to the questionnaire, the parents were informed that they had the right to refuse to participate in the study, that their responses are protected according to the information and Secrecy Act of each country. The parents were also told that the results would be published in international scientific journals and in reports in English and in national languages. The data was anonymized before the research team received it. All material has been kept in safe place.

\subsection{Statistical methods}

The indicators as described above were assessed as percentages of the study populations in the 1984, the 1996 and the 2011 sample of children aged 13-17 years in all Nordic countries according to sex and for each country separately. Changes in the indicators and indices of health, economy and social capital over time were defined and calculated as the difference in percentages 1984-1996, 1996-2011 and 19842011. Comparisons of percentages between years were done using conventional Chi-square tests. The symbols *, ** and $* * *$ refer to $p$-values less than $.05, .01$ and .001 , respectively.

\section{Results}

\subsection{Merged results from the five Nordic countries}

See Tables 1, 3 and Figures 1-4.

The Health Index deteriorated highly significantly in all the Nordic countries, both from 1984 to 1996, and from 1996 to 2011. The Economy Index improved significantly between 1984 and 1996, while there was no significant change between 1996 and 2011. Over the whole period 1984 to 2011, the Economy Index improved in a highly significant way. 
Table 1. Indicators and indices (percentages) in the samples from 1984, 1996 and 2011 for children aged 13-17 years by $\operatorname{sex}$

\begin{tabular}{|c|c|c|c|c|c|c|c|c|c|c|c|c|}
\hline & \multirow[b]{2}{*}{$\mathbf{N}$} & \multicolumn{2}{|l|}{ Health indicator } & \multicolumn{4}{|c|}{ Economic indicators } & \multicolumn{5}{|c|}{ Social capital indicators } \\
\hline & & $\begin{array}{l}\text { No psycho-somatic } \\
\text { complaints }\end{array}$ & $\begin{array}{l}\text { Health } \\
\text { index }\end{array}$ & $\begin{array}{l}\text { Middle or } \\
\text { upper class }\end{array}$ & $\begin{array}{l}\text { Two highest } \\
\text { income groups }\end{array}$ & $\begin{array}{l}\begin{array}{l}\text { Own } \\
\text { house }\end{array} \\
\end{array}$ & $\begin{array}{l}\text { Economic } \\
\text { index }\end{array}$ & $\begin{array}{l}\text { No experience } \\
\text { of bullying }\end{array}$ & $\begin{array}{l}\text { High group } \\
\text { activity }\end{array}$ & $\begin{array}{l}\text { Parents playing } \\
\text { a lot }\end{array}$ & $\begin{array}{l}\text { Parents' } \\
\text { position of trust }\end{array}$ & $\begin{array}{l}\text { Soc cap } \\
\text { index }\end{array}$ \\
\hline $\begin{array}{l}1984 \text { Total } \\
\text { sample }\end{array}$ & 2,905 & 77.5 & 77.5 & 56.6 & 52.8 & 74.3 & 61.2 & 92.9 & 20.1 & 31.9 & 40.1 & 46.3 \\
\hline Boys & 1,431 & 84.6 & 84.6 & 55.8 & 53.9 & 73.7 & 61.1 & 92.9 & 18.8 & 30.5 & 39.6 & 45.5 \\
\hline Girls & 1,474 & 70.4 & 70.4 & 57.4 & 51.7 & 74.9 & 61.3 & 92.9 & 21.3 & 33.2 & 40.6 & 47.0 \\
\hline $\begin{array}{l}1996 \text { Total } \\
\text { sample }\end{array}$ & 2,992 & 69.4 & 69.4 & 68.9 & 67.5 & 79.4 & 71.9 & 88.8 & 26.9 & 48.7 & 41.9 & 51.6 \\
\hline Girls & 1,456 & 62.8 & 62.8 & 67.3 & 66.3 & 79 & 70.9 & 90.3 & 26.8 & 46.5 & 42.5 & 51.5 \\
\hline $\begin{array}{l}2011 \text { Total } \\
\text { sample }\end{array}$ & 2,257 & 63.4 & 63.4 & 77.6 & 69 & 70.6 & 72.4 & 87.9 & 38.5 & 50.9 & 38.6 & 54.0 \\
\hline Boys & 1,100 & 69.5 & 69.5 & 85.5 & 70 & 67.9 & 74.5 & 89.1 & 37.6 & 51 & 39.4 & 54.3 \\
\hline Girls & 1,157 & 57.3 & 57.3 & 69.8 & 68 & 73.3 & 70.4 & 86.8 & 39.5 & 50.9 & 38.1 & 53.8 \\
\hline
\end{tabular}

The Social Capital Index also increased significantly from 1984 to 1996 but not from 1996 to 2011. Over the whole period 1984 to 2011 the improvement of the Social Capital Index was highly significant. Out of the included indicators in the Social Capital Index, children with no experience of bullying decreased over the two periods as did the par- ents' playing activities with the children, while the children's group activities increased significantly and parents' position of trust decreased a little. Thus, in this age group of Nordic children (13-17 years) the health complaints increased in spite of the fact that both economy and social capital increased in the families.

Table 2. Indicators and indices (percentages) in the samples from 1984, 1996 and 2011 for children aged 13-17 years by country and sex

\begin{tabular}{|c|c|c|c|c|c|c|c|c|c|c|c|c|}
\hline & \multirow[b]{2}{*}{$\mathbf{N}$} & \multicolumn{2}{|l|}{ Health indicator } & \multicolumn{4}{|c|}{ Economic indicators } & \multicolumn{5}{|c|}{ Social capital indicators } \\
\hline & & $\begin{array}{l}\text { No psycho-somatic } \\
\text { complaints }\end{array}$ & $\begin{array}{l}\text { Health } \\
\text { index }\end{array}$ & $\begin{array}{l}\text { Middle or } \\
\text { upper class }\end{array}$ & $\begin{array}{l}\text { Two highest } \\
\text { income groups }\end{array}$ & $\begin{array}{l}\text { Own } \\
\text { house }\end{array}$ & $\begin{array}{l}\text { Economic } \\
\text { index }\end{array}$ & $\begin{array}{l}\text { No experience } \\
\text { of bullying }\end{array}$ & $\begin{array}{l}\text { Child's group } \\
\text { acitivty }\end{array}$ & $\begin{array}{l}\text { Parents palying } \\
\text { with the child }\end{array}$ & $\begin{array}{l}\text { Parents' } \\
\text { position of trust }\end{array}$ & $\begin{array}{l}\text { Soc cap } \\
\text { index }\end{array}$ \\
\hline Denmark 1984 & 627 & 81.1 & 81.1 & 49.1 & 56.4 & 71.1 & 58.9 & 91.1 & 17.9 & 33.6 & 35.9 & 44.6 \\
\hline Boys & 310 & 87.4 & 87.4 & 50.2 & 59.8 & 73.9 & 61.3 & 90.8 & 16.2 & 30.9 & 35.2 & 43.3 \\
\hline Denmark 1996 & 655 & 67.9 & 67.9 & 68.1 & 76.2 & 82.1 & 75.5 & 81 & 18.5 & 28.2 & 37.7 & 41.4 \\
\hline Boys & 335 & 72.2 & 72.2 & 67.5 & 77.9 & 84.5 & 76.6 & 78.5 & 19.2 & 27.8 & 35.4 & 40.2 \\
\hline Girls & 320 & 63.1 & 63.1 & 68.7 & 74.5 & 79.7 & 74.3 & 83.5 & 17.7 & 28.6 & 40.1 & 42.5 \\
\hline Denmark 2011 & 506 & 87.8 & 57.3 & 75.7 & 69.1 & 74.6 & 73.1 & 78.4 & 25.4 & 59.5 & 25.1 & 47.1 \\
\hline Boys & 233 & 62.2 & 62.2 & 65.8 & 68.8 & 75.1 & 69.9 & 81.1 & 27.4 & 64.8 & 28.6 & 50.5 \\
\hline Girls & 273 & 53.1 & 53.1 & 72.2 & 69.4 & 74.1 & 71.9 & 75.7 & 23.5 & 54.1 & 22 & 43.8 \\
\hline Finland 1984 & 819 & 72.5 & 72.5 & 53.4 & 43.6 & 70.6 & 55.9 & 92.9 & 19.7 & 42.5 & 33.7 & 47.2 \\
\hline Boys & 368 & 81 & 81 & 64.4 & 42.1 & 67.9 & 58.1 & 92.5 & 18.1 & 40.2 & 33 & 46.0 \\
\hline Girls & 451 & 65.6 & 65.6 & 63.4 & 45.2 & 73.3 & 60.6 & 93.3 & 21.3 & 44.7 & 34.5 & 48.5 \\
\hline Finland 1996 & 631 & 69.1 & 69.1 & 63.9 & 58.4 & 86 & 69.4 & 91.2 & 14.9 & 35.4 & 31.5 & 43.3 \\
\hline Boys & 312 & 77.9 & 77.9 & 64.4 & 59.7 & 91.1 & 71.7 & 89 & 15.2 & 36.9 & 32.5 & 43.4 \\
\hline Girls & 319 & 60.2 & 60.2 & 63.4 & 57 & 80.9 & 67.1 & 93.4 & 14.7 & 33.9 & 30.5 & 43.1 \\
\hline Finland 2011 & 394 & 65.7 & 65.7 & 67.4 & 75.8 & 86 & 76.4 & 90.9 & 22.7 & 51.4 & 38.1 & 50.8 \\
\hline Boys & 198 & 75.8 & 75.8 & 79.3 & 79.3 & 91.1 & 83.2 & 92.4 & 23.2 & 55.8 & 34.5 & 51.5 \\
\hline Girls & 196 & 55.6 & 55.6 & 72.2 & 72.2 & 80.9 & 75.1 & 89.4 & 22.3 & 47 & 41.8 & 50.1 \\
\hline Girls & 181 & 64.1 & 64.1 & 54.9 & 67.9 & 69.1 & 64.0 & 90.9 & 33.5 & 44.4 & 36.3 & 51.3 \\
\hline Iceland 1996 & 558 & 68.8 & 68.8 & 58.1 & 58.1 & 56.9 & 57.7 & 90.7 & 48.5 & 46.3 & 42.8 & 57.1 \\
\hline Boys & 290 & 74.8 & 74.8 & 61.8 & 61.8 & 56.4 & 60.0 & 90.4 & 46.5 & 47.7 & 41.8 & 56.6 \\
\hline Girls & 268 & 62.3 & 62.3 & 54.5 & 54.5 & 57.5 & 55.5 & 90.9 & 50.6 & 44.8 & 43.9 & 57.6 \\
\hline Iceland 2011 & 485 & 60.0 & 60.0 & 72.1 & 63.3 & 70.7 & 68.7 & 86.6 & 48.6 & 53.2 & 42.6 & 57.8 \\
\hline Boys & 255 & 65.8 & 65.8 & 71.5 & 66.3 & 73.3 & 70.4 & 87.1 & 43.3 & 53.3 & 44.5 & 57.1 \\
\hline Girls & 230 & 54.2 & 54.2 & 72.7 & 60.3 & 68.0 & 67.0 & 86.0 & 53.8 & 53.1 & 40.7 & 58.4 \\
\hline Norway 1984 & 550 & 78.9 & 78.9 & 62.7 & 54.8 & 84.3 & 67.3 & 92.3 & 21.4 & 54.5 & 61.3 & 57.4 \\
\hline Boys & 284 & 84.9 & 84.9 & 62.2 & 57.2 & 82.0 & 67.1 & 93.8 & 20.2 & 55.6 & 59.2 & 57.2 \\
\hline Girls & 266 & 72.6 & 72.6 & 63.2 & 52.6 & 86.6 & 67.5 & 90.8 & 22.7 & 53.3 & 63.4 & 57.6 \\
\hline Norway 1996 & 532 & 68.6 & 68.6 & 78.5 & 78.9 & 91.5 & 83.0 & 87.7 & 15.5 & 55.3 & 57.9 & 54.1 \\
\hline Boys & 76.1 & 74.4 & 74.4 & 77.4 & 80.9 & 90.9 & 83.1 & 86.1 & 18.4 & 61.3 & 59.1 & 56.2 \\
\hline Girls & 61.6 & 79.5 & 79.5 & 79.5 & 76.8 & 92.1 & 82.8 & 89.4 & 12.6 & 49.3 & 56.7 & 52.0 \\
\hline Norway 2011 & 514 & 67.1 & 67.1 & --- & 78.9 & 87.6 & 83.3 & 91.3 & 13.6 & 46.7 & 51.4 & 50.8 \\
\hline Boys & 276 & 71.6 & 71.6 & & 80.9 & 87.6 & 84.3 & 92.9 & 13 & 42.3 & 49.8 & 49.5 \\
\hline Girls & 256 & 62.6 & 62.6 & & 76.8 & 87.5 & 82.2 & 89.6 & 14.1 & 51.2 & 53 & 52.0 \\
\hline Sweden 1984 & 563 & 82.2 & 82.2 & 65.6 & 50.0 & 75.1 & 63.6 & 94.7 & 27.9 & 29.0 & 35.1 & 46.7 \\
\hline Boys & 304 & 87.8 & 87.8 & 65.2 & 50.4 & 72.2 & 62.6 & 94.2 & 24.8 & 30.4 & 34.8 & 46.1 \\
\hline Girls & 259 & 75.7 & 75.7 & 66.0 & 49.6 & 78.0 & 64.5 & 95.3 & 30.9 & 27.6 & 35.4 & 47.3 \\
\hline Sweden 1996 & 616 & 73.4 & 73.4 & 76.1 & 61.4 & 75.8 & 71.1 & 94.1 & 40.9 & 22.8 & 40.9 & 49.7 \\
\hline Sweden 2011 & 449 & 66.0 & 66.0 & 63.4 & 67.8 & 75.7 & 69.0 & 93.6 & 43.0 & 43.2 & 35.6 & 53.9 \\
\hline Boys & 216 & 72.1 & 72.1 & 56.9 & 68.2 & 74.4 & 66.5 & 92.0 & 44.1 & 39.7 & 37.4 & 53.3 \\
\hline Girls & 233 & 59.9 & 59.9 & 65.9 & 67.3 & 76.9 & 70.0 & 95.2 & 41.9 & 46.7 & 33.9 & 54.4 \\
\hline
\end{tabular}




\subsection{Results from the separate Nordic countries}

See Tables 2, 3, 4.

\subsubsection{Denmark}

Children in Denmark were from the beginning, together with children in Sweden, least afflicted with PSC, but the prevalence of PSC increased and in 2011. Danish children had more PSC than children in any of the other countries. The Economy Index rose to a higher standard, particularly and significantly in the early period, and reached a middle position among the countries. The Social Capital Index did not change much for each period, but when studying the three surveys, the decrease became statistically significant. The in dicator "Parents' playing with the children" decreased during all periods. The children's experience of bullying increased significantly 1984-2011, mostly in the first period, while the "Child's group activity" increased significantly totally and mainly in the second period.

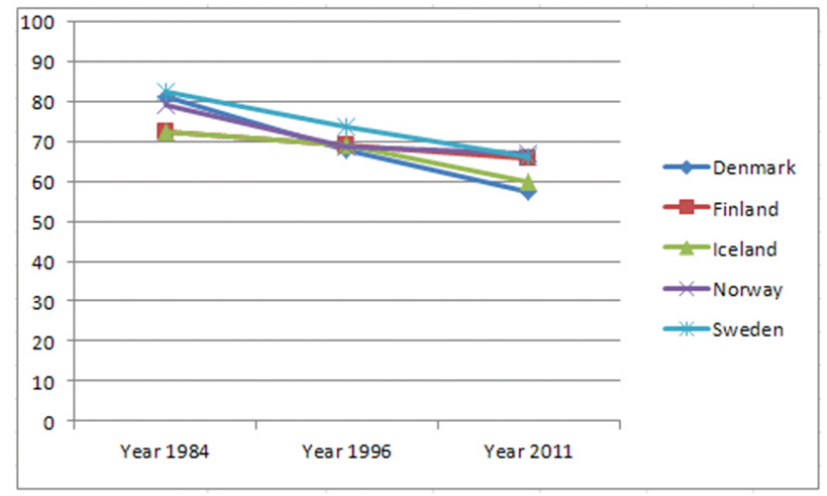

Figure 1. Health Index for children aged 13-17 years in the samples from 1984, 1996 and 2011 by country

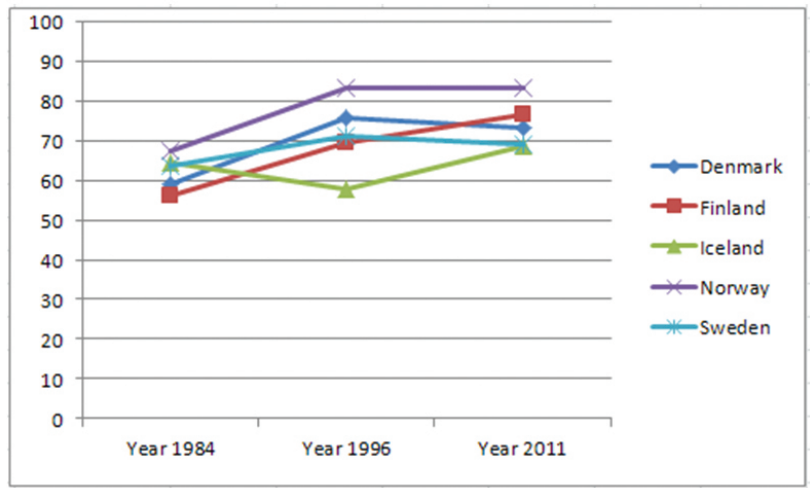

Figure 2. Economy Index for children aged 13-17 years in the samples from 1984, 1996 and 2011 by country

\subsubsection{Finland}

The prevalence of PSC increased slightly over both periods, while the economy improved significantly in the first period but not in the second one. The improvement from 1984 to 2011 was highly statistically significant. The Social Capital Index remained virtually unchanged, while the parts "Parents' playing with the children" decreased significantly during all periods and "Child's group activity" increased in the second period and totally.

\subsubsection{Iceland}

The Health Index worsened significantly for the whole period 1984-2011 although there was no change for the first period 1984-1996. The Economy Index decreased during the first period and increased during the second period although not significantly. The Social Capital Index increased slightly over time. "Child's group activity" was the only indicator of the Social Capital Index that improved significantly and in both periods, while the experience of being bullied increased slightly 2011. For the whole period, from 1984 to 2011, Icelandic children experienced increased bullying, but also increased group activities and "Parents' playing with the children".

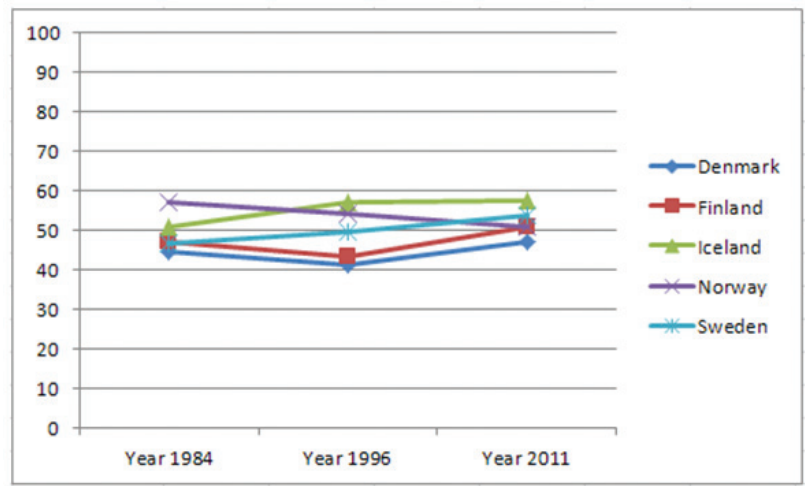

Figure 3. Social Capital Index for children aged 13-17 years in the samples from 1984, 1996 and 2011 by country

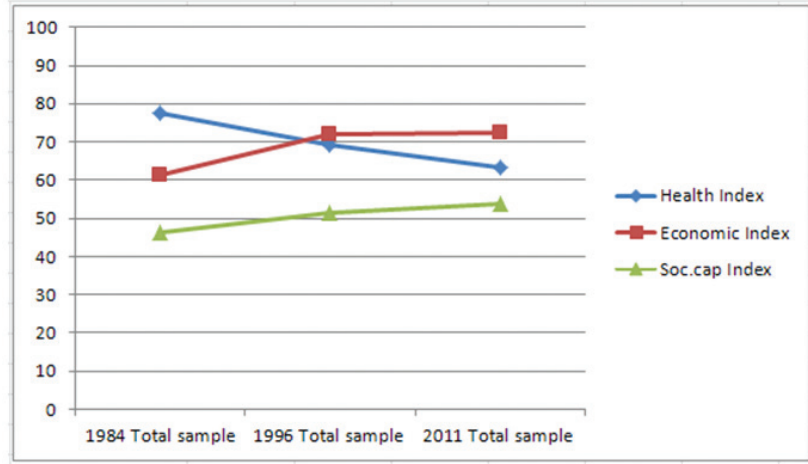

Figure 4. Indices of Health, Economy and Social Capital for children aged 13-17 years in the 5 Nordic countries in the samples from 1984, 1996 and 2011 


\subsubsection{Norway}

The Health Index worsened significantly in the first period and did not change in the second. The Economy Index improved significantly in the first period, keeping Norway well in top among the Nordic countries through both study periods. The Social Capital Index did not vary much over time.

\subsubsection{Sweden}

The Health Index started out as the best one of all countries in 1984, kept the rank in 1996, but fell to second place in 2011 (Norway having the highest). The Economy Index increased slightly, particularly in the first period. The Social Capital Index remained roughly the same over time, although there was a different development between the included indicators: "Child's group activity" increased significantly, in both periods, while "Parents' playing with the children" was reduced correspondingly.

\subsection{Boys and girls}

The Health Index was generally lower in girls than boys, but it decreased significantly in both sexes over time. The Economy Index was somewhat better in families with boys, but improved significantly for both sexes, for the first period and from 1984 to 2011. The Social Capital Index reached similar values for both boys and girls and increased just like the Economy Index for both sexes, i.e. significantly for the first period and together for both periods.

\section{Discussion}

In a broad international perspective, the Nordic countries taken together are often seen as a quite homogenous group. These three cross-sectional surveys (1984, 1996 and 2011) of the development of health, economy and social capitals of 13-17 year old children confirm the picture, but they also show variations.

Table 3. Index changes (percentages) in the samples from 1984, 1996 and 2011 for children aged 13-17 years by country and sex

\begin{tabular}{|c|c|c|c|c|c|c|c|c|c|c|c|c|c|c|c|c|c|c|}
\hline & \multicolumn{6}{|c|}{ Health Index Changes } & \multicolumn{6}{|c|}{ Economy Index changes } & \multicolumn{6}{|c|}{ Social Capital Index } \\
\hline & 1984-1996 & $p$-value & 1996-2011 & $p$-value & 1984-2011 & $p$-value & 1984-1996 & $p$-value & 1996-2011 & $p$-value & 1984-2011 & $p$-value & 1984-1996 & $p$-value & 1996-2011 & $p$-value & 1984-2011 & $p$-value \\
\hline \multicolumn{19}{|l|}{ Denmark } \\
\hline Total & -13.2 & $* * *$ & -10.5 & *** & -23.7 & *** & 16.6 & $* * *$ & 5.2 & ** & 21.8 & NS & -2.3 & NS & -1.5 & NS & -3.9 & $* *$ \\
\hline Boys & -15.0 & $* * *$ & -10.2 & * & -25.2 & $* * *$ & 15.5 & $* * *$ & 3.7 & * & 19.3 & NS & -3.5 & NS & 2.1 & NS & -1.5 & NS \\
\hline Girls & -11.6 & ** & -10.0 & * & -21.6 & $* * *$ & 17.6 & $* * *$ & 6.7 & NS & 24.3 & $*$ & -1.2 & NS & -4.7 & $*$ & -5.9 & $*$ \\
\hline \multicolumn{19}{|l|}{ Finland } \\
\hline Total & -3.1 & NS & -3.5 & NS & -6.6 & * & 11.7 & *** & 7.0 & NS & 18.7 & **** & -2.7 & NS & 4.0 & NS & 1.2 & NS \\
\hline Boys & -2.9 & NS & -2.3 & $\mathrm{~N}$ & -5.2 & NS & 14.6 & $* * *$ & 8.8 & NS & 23.4 & *** & -3.1 & NS & 4.4 & NS & 1.3 & NS \\
\hline Girls & -5.0 & NS & -4.6 & NS & -9.6 & $*$ & 9.3 & $*$ & 5.4 & NS & 14.7 & * & -2.3 & NS & 3.5 & ${ }_{* *}^{*}$ & 1.2 & $*$ \\
\hline \multicolumn{19}{|l|}{ Iceland } \\
\hline Total & -3.4 & NS & -9.3 & ** & -12.7 & *** & -3.6 & NS & 10.4 & NS & 6.8 & NS & 5.4 & NS & 9.5 & NS & 14.9 & * \\
\hline Girls & -1.8 & NS & -8.8 & * & -10.6 & $*$ & -3.9 & NS & 7.4 & NS & 3.6 & NS & 5.5 & NS & 9.5 & NS & 15.0 & NS \\
\hline \multicolumn{19}{|l|}{ Norway } \\
\hline Total & -9.9 & $* * *$ & -1.4 & NS & -11.3 & $* * *$ & 15.6 & $* * *$ & -0.6 & NS & 14.9 & NS & -3.2 & NS & -1.1 & * & -4.2 & NS \\
\hline Boys & -8.7 & $* *$ & -4.9 & NS & -13.6 & $* * *$ & 15.9 & $* * *$ & 0.4 & NS & 16.7 & $*$ & -1.0 & NS & -4.0 & NS & -5.0 & NS \\
\hline Girls & -11.0 & $* *$ & 2.4 & NS & -8.6 & $*$ & 15.3 & $* *$ & -1.6 & NS & 13.1 & NS & -5.5 & NS & 2.0 & NS & -3.5 & NS \\
\hline \multicolumn{19}{|l|}{ Sweden } \\
\hline Total & -8.6 & $* * *$ & -7.6 & ** & -16.2 & *** & 9.3 & NS & 0.4 & NS & 9.7 & NS & 2.9 & NS & -1.7 & NS & 1.2 & NS \\
\hline Boys & -8.0 & $* *$ & -7.6 & * & -15.7 & $* * *$ & 12.7 & $*$ & -3.8 & NS & 8.9 & NS & 2.4 & NS & -2.3 & NS & 0.1 & NS \\
\hline Girls & -8.8 & * & -6.5 & NS & -15.2 & $* * *$ & 5.5 & NS & 4.8 & NS & 10.3 & NS & 3.4 & NS & -1.1 & NS & 2.3 & NS \\
\hline \multicolumn{19}{|l|}{$\begin{array}{l}\text { All Nordic } \\
\text { countries }\end{array}$} \\
\hline Total & -8.1 & $* * *$ & -6 & $* * *$ & -14.1 & $* * *$ & 10.7 & $* * *$ & 0.5 & NS & 11.2 & $* * *$ & 5.4 & $* * *$ & 2.4 & NS & 7.8 & $* * *$ \\
\hline Girls & -7.6 & $* * *$ & -5.5 & $* *$ & -13.1 & $* * *$ & 9.6 & $* * *$ & -0.5 & NS & 9.1 & $* * *$ & 4.5 & $*$ & 2.3 & NS & 6.8 & $* * *$ \\
\hline
\end{tabular}

Overall in the Nordic countries the Health Index decreased over both periods (1984-1996, 1996-2011), while the Economic and Social Capital Indices increased during the first period but not during the second one, showing a significant increase for the two periods taken together, 1984-2011. In a previous study of Nordic children 2-17 years old Berntsson, [2006] showed that between 1984 and 1996, the indicator for Health deteriorated as did those for the Social Capital while those for the Economy improved. In the present study, we have combined the different outcome indicators to three composite indices and we have found that the changes mainly took place in the first period, 1984-1996. However, the changes varied between different indicators, different periods and between countries.

Combining a group of indicators into a composite index is an often practiced method used to summarize a complex picture in order to make it more comprehensive and easy to understand. On the other hand, it may also obscure differences and mislead interpretations. ${ }^{[32]}$ By using separate indicators as well as composite indices, we have in this study tried to satisfy both the need for simplification and for accurate interpretations.

In general, children's living conditions are good in the Nordic countries, but the previous constant progress of the children's health and wellbeing seems to have ceased, involving worsened mental health. A large part of this development is explained by political and structural changes and particularly the increasing societal inequity is found to be crucial for people's economy, education, status, health and wellbeing. ${ }^{[33-38]}$ An analysis of different demographic and social variables in various relevant subgroups should be made in further studies. 
Table 4. Indicator changes (percentages) in the samples from 1984, 1996 and 2011 for children aged 13-17 years by country and sex

\begin{tabular}{|c|c|c|c|c|c|c|c|c|}
\hline & \multirow{2}{*}{$\begin{array}{l}\text { Health indicator } \\
\text { No Psycho-somatic } \\
\text { complaints }\end{array}$} & \multicolumn{3}{|c|}{ Economic indicators } & \multicolumn{3}{|c|}{ Social Capital Indicators } & \multirow[b]{2}{*}{$\begin{array}{l}\text { Parents' } \\
\text { position of trust }\end{array}$} \\
\hline & & $\begin{array}{l}\text { Middle or } \\
\text { Upper class }\end{array}$ & $\begin{array}{l}\text { High income. Two } \\
\text { highest groups }\end{array}$ & $\begin{array}{l}\text { Own } \\
\text { house }\end{array}$ & $\begin{array}{l}\text { No experience } \\
\text { of bullying }\end{array}$ & $\begin{array}{l}\text { High group } \\
\text { activity }\end{array}$ & $\begin{array}{l}\text { Parents } \\
\text { playing a lot }\end{array}$ & \\
\hline \multicolumn{9}{|c|}{ Denmark 1984-1996 } \\
\hline Total & $-13.2^{* * *}$ & $+19.1^{* * *}$ & $+19.8^{* * *}$ & $+10.9^{* * *}$ & $-10.2^{* * *}$ & +0.8 & -2.5 & +2.5 \\
\hline Boys & $-15.0^{* * *}$ & $+18.0^{* * *}$ & $+18.1^{* * *}$ & $+10.5^{* *}$ & $-12.4^{* * *}$ & +3.7 & -6.8 & 1.4 \\
\hline Girls & $-11.6^{* *}$ & $+20.2^{* * *}$ & $+21.4^{* * *}$ & $+11.3^{* *}$ & $-7.9^{* *}$ & -2.1 & +1.6 & +3.6 \\
\hline \multicolumn{9}{|c|}{ Denmark 1996-2011 } \\
\hline Total & $-10.5^{* * *}$ & $+29.7^{* * *}$ & $-6.7^{*}$ & $-7.5^{* *}$ & -2.7 & $+13.7^{* * *}$ & -3.7 & $-13.4^{* * *}$ \\
\hline Boys & $-10.2^{*}$ & $+28.3^{* * *}$ & -7.7 & $-9.3^{* *}$ & +2.8 & $+11.8^{* *}$ & +1.7 & -7.9 \\
\hline Girls & $-10.0^{*}$ & $+31.1^{* * *}$ & -5.6 & -5.4 & $-7.8^{*}$ & $+15.5^{* * *}$ & -8.4 & $-18.3^{* * *}$ \\
\hline \multicolumn{9}{|c|}{ Denmark 1984-2011 } \\
\hline Total & $-23.7^{* * *}$ & $+48.8^{* * * *}$ & $+13.0^{* * *}$ & +3.5 & $-12,8^{* * *}$ & $+14.5^{* * *}$ & $-6.2^{*}$ & $-10.9^{* * *}$ \\
\hline Boys & $-25.2^{* * * *}$ & $+46.3^{* * * *}$ & $+10.3^{*}$ & +1.2 & $-9.6^{* *}$ & $+15.5^{* * *}$ & -5.1 & -6.6 \\
\hline Girls & $-21.6^{* * *}$ & $+51.3^{* * *}$ & $+15.7^{* * *}$ & +5.8 & $-15.7^{* * *}$ & $+13.4^{* * * *}$ & -6.8 & $-14.7^{* * *}$ \\
\hline \multicolumn{9}{|c|}{ Finland 1984-1996 } \\
\hline Total & -3.1 & $+10.6^{* * *}$ & $+14.5^{* * *}$ & $+10.0^{* * *}$ & -0.8 & +2.1 & $-10.8^{* * *}$ & -2.2 \\
\hline Boys & -2.9 & $+14.4^{* * *}$ & $+17.6^{* * *}$ & $+11.9^{* * *}$ & -3.4 & +0.8 & $-9.8^{* *}$ & -0.1 \\
\hline Girls & -4.9 & +7.2 & $+11.8^{* *}$ & $+8.8^{* *}$ & $+3.3^{*}$ & +3.9 & $-12.2^{* *}$ & -4.2 \\
\hline Total & -3.5 & $+11.4^{* * * *}$ & +4.5 & $+5.1^{*}$ & -1.9 & $+21.3^{* * *}$ & $-9.8^{* *}$ & $+6.4^{*}$ \\
\hline Boys & -2.3 & $+14.3^{* *}$ & +0.5 & $+11.5^{* * *}$ & +2.9 & $+19.3^{* * *}$ & -6.4 & +1.6 \\
\hline Girls & -4.6 & +8.9 & +8.7 & -1.2 & $-6.9^{* *}$ & $+23.1^{* * * *}$ & $-13.8^{* *}$ & $+11.5^{*}$ \\
\hline Finland & & & & & & & & \\
\hline Total & $-6.6^{*}$ & $+22.0^{* * *}$ & $+19.0^{* * *}$ & $+15.2^{* * *}$ & -2.0 & $+23.4^{* * *}$ & $-20.6^{* * *}$ & +4.3 \\
\hline Boys & -5.2 & $+28.7^{* * *}$ & $+18.1^{* * *}$ & $+23.3^{* * *}$ & -0.4 & $+20.1^{* * *}$ & $-16.2^{* * * *}$ & +1.4 \\
\hline Girls & $-9.6^{*}$ & $+16.1^{* * * *}$ & $+20.4^{* * *}$ & $+7.6^{*}$ & -3.6 & $+26.9^{* * *}$ & $-25.9^{* * * *}$ & +7.3 \\
\hline Iceland & & & & & & & & \\
\hline Total & -3.4 & +6.1 & $-12.2^{* * *}$ & -4.8 & -3.2 & $+15.2^{* * *}$ & +3.5 & +6.2 \\
\hline Boys & -6.4 & $+12.4^{*}$ & $-14.2^{* *}$ & $-8.9^{*}$ & -4.6 & $+13.6^{* *}$ & +6.6 & +4.8 \\
\hline Girls & -1.8 & -0.4 & $-10.4^{*}$ & -0.9 & -3.9 & $+17.0^{* * *}$ & +0.3 & +7.6 \\
\hline Iceland & & & & & & & & \\
\hline Total & $-9.3^{* *}$ & $+23.4^{* * *}$ & +3.9 & +4.0 & $-4.0^{*}$ & $+35.2^{* * *}$ & $+6.8^{*}$ & -0.1 \\
\hline Boys & $-9.0^{*}$ & $+23.4^{* * *}$ & $+9.3^{*}$ & +7.6 & -2.1 & $+32.8^{* * *}$ & +5.4 & +2.8 \\
\hline Girls & $-8.8^{*}$ & $+23.7^{* * *}$ & -1.6 & +0.3 & -4.7 & $+37.4^{* * * *}$ & +8.5 & -3.1 \\
\hline Iceland & & & & & & & & \\
\hline Total & $-12.7^{* * *}$ & $+29.5^{* * *}$ & $-8.3^{*}$ & -0.9 & $-7.2^{* *}$ & $+50.4^{* * *}$ & $+10.3^{* *}$ & +6.0 \\
\hline Boys & $-15.4^{* * * *}$ & $+35.8^{* * *}$ & -4.8 & -1.3 & $-6.7^{*}$ & $+46.5^{* * *}$ & $+11.9^{*}$ & +7.5 \\
\hline Total & $-9.9^{* * *}$ & $+15.7^{* * *}$ & $+23.8^{* * *}$ & $+7.3^{* * *}$ & $-4.6^{*}$ & $-5.9^{*}$ & +1.1 & -3.3 \\
\hline Boys & $-8.7^{* *}$ & $+15.2^{* * *}$ & $+23.5^{* * *}$ & $+8.9^{* *}$ & $-7.7^{* *}$ & -2.9 & +5.7 & -0.5 \\
\hline Girls & $-10.9^{* *}$ & $+16.2^{* * *}$ & $+24.1^{* * *}$ & $+5.4^{*}$ & -1.4 & $-10.1^{* *}$ & -3.9 & -6.7 \\
\hline Norway & & & & & & & & \\
\hline Total & -1.4 & --- & +2.9 & $-4.2^{*}$ & +3.5 & $+6.4^{*}$ & $-7.4^{*}$ & $-6.8^{*}$ \\
\hline Boys & $-4.9^{*}$ & ---- & +4.5 & -3.7 & $+6.3^{*}$ & +4.1 & $-16.4^{* * * *}$ & $-10.2^{*}$ \\
\hline Girls & +2.4 & --- & +1.4 & -4.7 & +0.6 & $+8.8^{* *}$ & +2.2 & -3.4 \\
\hline Norway & & & & & & & & \\
\hline Total & $-11.3^{* * *}$ & --- & $+26.8^{* * *}$ & +3.1 & -1.0 & +0.5 & $-6.3^{*}$ & $-10.1^{* *}$ \\
\hline Boys & $-13.6^{* * *}$ & --- & $+28.1^{* * *}$ & +5.3 & -1.3 & +2.2 & $-10.7^{*}$ & $-10.3^{*}$ \\
\hline Girls & $-8.6^{*}$ & --- & $+25.5^{* * *}$ & +0.7 & -0.7 & -1.3 & -1.8 & $-10.1^{*}$ \\
\hline Sweden & & & & & & & & \\
\hline Total & $-8.6^{* *}$ & $+10.3^{* * *}$ & $+16.5^{* * *}$ & +1.0 & -0.5 & $+13.4^{* * *}$ & $-6.5^{*}$ & +5.2 \\
\hline Boys & $-8.0^{* *}$ & $+15.7^{* * *}$ & $+16.9^{* * *}$ & +5.5 & -0.7 & $+16.7^{* * *}$ & $-9.3^{*}$ & +3.1 \\
\hline Girls & $-8.8^{*}$ & +04.4 & $+16.1^{* * *}$ & -4.1 & -0.3 & $+9.6^{*}$ & -3.3 & +7.5 \\
\hline Sweden & & & & & & & & \\
\hline Total & $-7.6^{* *}$ & +4.7 & -0.9 & -2.5 & -0.4 & $+11.4^{* * *}$ & $-12.3^{* * * *}$ & -5.3 \\
\hline Boys & $-7.6^{*}$ & -3.4 & -3.1 & -4.9 & -1.7 & $+11.3^{*}$ & $-17.1^{* * *}$ & -1.7 \\
\hline Girls & -6.5 & $+13.1^{* *}$ & +1.1 & +0.1 & +0.5 & $+11.5^{* *}$ & -7.6 & $-8.9^{*}$ \\
\hline Sweden & & & & & & & & \\
\hline Total & $-16.2^{* * *}$ & $+15.1^{* * *}$ & $+15.6^{* * *}$ & -1.4 & -0.9 & $+24.8^{* * *}$ & $-18.8^{* * *}$ & -1.0 \\
\hline Boys & $-15.7^{* * *}$ & $+12.2^{*}$ & $+13.8^{* *}$ & +0.6 & -2.4 & $+27.9^{* * *}$ & $-26.4^{* * *}$ & +1.4 \\
\hline Girls & $-15.2^{* * *}$ & $+17.6^{* * *}$ & $+17.2^{* * *}$ & -3.9 & $\begin{array}{l}-0.3 \\
+0.3\end{array}$ & $+21.2^{* * *}$ & $-10.9^{*}$ & -1.5 \\
\hline All coun & & & & & & & & \\
\hline Total & $-7.7^{* * *}$ & $+12.3^{* * *}$ & $+14.7^{* * *}$ & $+4.9^{* * *}$ & $-3.9^{* * *}$ & $+7.0^{* * *}$ & $-5.6^{* * *}$ & +1.7 \\
\hline Boys & $-8.4^{* * * *}$ & $+14.8^{* * *}$ & $+14.8^{* * *}$ & $+5.8^{* * *}$ & $-5.4^{* * *}$ & $+8.3^{* * *}$ & $-5.4^{* *}$ & +1.7 \\
\hline Girls & $-7.5^{* * *}$ & $+9.7^{* * * *}$ & $+14.6^{* * *}$ & $+4.0^{*}$ & $-2.5^{* * *}$ & $+5.7^{* * *}$ & $-5.9^{* *}$ & +1.9 \\
\hline All coun & & & & & & & & \\
\hline Total & $-6.6^{* * *}$ & $+15.4^{* * *}$ & -0.1 & -1.0 & -0.9 & $+21.1^{* * *}$ & $-5.4^{* * *}$ & $-3.5^{*}$ \\
\hline Boys & $-7.0^{* * *}$ & $+11.4^{* * *}$ & -0.1 & +0.2 & +1.3 & $+19.8^{* * *}$ & $-6.8^{* * *}$ & -2.4 \\
\hline Girls & $-5.4^{* *}$ & $+16.5^{* * *}$ & +0.1 & -2.2 & -2.2 & $+22.4^{* * *}$ & -3.8 & $-4.6^{*}$ \\
\hline All coun & & & & & & & & \\
\hline Total & $-14.2^{* * *}$ & $+27.7^{* * *}$ & $+14.7^{* * *}$ & $+3.9^{* *}$ & $-4.9^{* * *}$ & $+28.1^{* * *}$ & $-10.9^{* * *}$ & -1.8 \\
\hline Boys & $-15.4^{* * * *}$ & $+26.1^{* * *}$ & $+14,7^{* * *}$ & $+5.9^{* * *}$ & $-4.1^{* * *}$ & $+28.1^{* * *}$ & $-12.2^{* * * *}$ & -0.7 \\
\hline Girls & $-12.9^{* * *}$ & +26.2 & $-23.6^{* * *}$ & +1.9 & $-14.4^{* * *}$ & $+28.1^{* * *}$ & $-9.8^{* * *}$ & -2.8 \\
\hline
\end{tabular}


The deteriorating psychosomatic health among teenagers is a common experience in many affluent countries and has been explained by increased stressful environments, particularly blaming the school system for not functioning properly. ${ }^{[38-40]}$ There is a growing proportion of young people leaving compulsory school without qualifications for further studies, and on top of that, there are great problems with young people's integration into the labor markets. ${ }^{[41]}$ However, there are also other factors that could influence the development of PSC: these kinds of unwanted problems are less accepted today than they were 25 years ago, both by children and parents, and physical health problems have disappeared or diminished from the youngsters' lives, which might open up for new and "milder" concerns.

The most outstanding decrease of the Health Index was found in Denmark which coincides with particularly high prevalence of bullying. Lereya et al. ${ }^{[42]}$ have shown that being bullied by peers in childhood has generally long-term adverse effects on young adult's mental health. In a qualitative study the parents of Nordic pre-school children described how they suffered from time-pressure. ${ }^{[43]}$ It is well-known that the children's health are closely connected to those of their parents, particularly the mother's. ${ }^{[3]}$

The Economy Index was quite high in all countries from the beginning, and then increased significantly in the first period, except for Iceland and Sweden, which were both in deep economic recessions with high unemployment and reduced social security. The index remained stable in the second period, indicating a stabilizing economy. It increased only in Denmark, and the summarized increase for both periods was significant only in Finland, a country recovering fast from its economic recession. Being one of the world's richest countries due to its huge and growing incomes from the oil sources, Norway also had the richest families. ${ }^{[44]}$ Iceland has a traditionally fluctuating economy, since it is heavily depending on only one major industry, namely fishing.

The Social Capital Index was the highest and the most stable in Iceland and Norway. The indicator "The child's group activity" seems to be an important factor in all countries. It has earlier been reported that a high activity level in sports was related to less PSC and well-being in children 7-17 years old. ${ }^{[8,45]}$ In another study by Jago et al. ${ }^{[46]}$ the importance of physical activity of youth/young people might suggest that friends and friendship groups influence the initiation and maintenance of physical activity of young people. Two of the variables in the Social Capital Index, "No experience of bullying" and "Parents' playing with the children" diminished significantly for both periods together. "Parents' position of trust" did not change much, but the positive development of "Child's group activity" increased, and thus counterbalanced the negative ones, a not too uncommon phenomenon in composite indices. ${ }^{[32]}$ For future studies, a new analysis must be made of actual and relevant variables for a proper measurement of Social Capital, a concept that is complex and shifting over time and place.

\section{Conclusion}

For both study periods (1984 to 1996 and 1996 to 2011) there was a significant increase of psychosomatic health complaints in Nordic children 13-17 years of age especially among girls. For the first period (1984 to 1996) the economy and social capital of the families increased and remained stable in the second period (1996 to 2011) with a statistical significance for the summarized two periods.

The increase of PSC in teenagers is in line with many other studies, in the Nordic countries as well in most of the Western world, ${ }^{[38-40,47]}$ as is the gender difference. ${ }^{[48]}$ It is perhaps not expected that the increase happens in conjunction with improved family economy, but it is not a new phenomenon. ${ }^{[7]}$ More surprising, however, is that neither the increasing indices of Social Capital and Economy seem to be able to protect against worsened health. Other studies, both from the Nordic countries and elsewhere, have shown that social capital in the family, at school and in the neighborhood has a positive influence on the children's health and wellbeing. ${ }^{[7,37,38,49]}$ The study supports conclusions from other studies stating that a general economic growth is not enough for the wellbeing of the population. It also supports the importance of the social cohesion, affiliation and solidarity, advanced and reinforced by equal distribution of the wealth. ${ }^{[33,35,37,50]}$

\subsection{The study's strengths and limitations}

A strength of this study is that the time during which data was collected stretches over considerable time (1984-2011) in all the Nordic countries and that basically the same methods were used. This gives the opportunity to consider long-term changes in the social, economic, cultural and human capital situations. However, it is a historical fact that symptoms, health behavior and perception of one's life situation conform to the spirit of the time in the actual society. It implies that the perception and expression of both psychosocial problems and life conditions may change considerably over time and that the interpretation of the questions in the questionnaire may also change, for the children as well as for the parents. Since more than 25 years have elapsed between the first and the third study, the results should be interpreted with care, and rather, encourage further development of the measuring tools. The cross-sectional design of this study does not allow 
for any firm conclusions about causality.

We have analyzed only a few factors, which may be included in the indices. Especially Social Capital is a complex concept covering different aspects of, children's lives, where results for different components may be conflicting. There may also be other factors that predict differences in health, family economy and social capital and which should be analyzed in the future, particularly the increasing societal inequities among subgroups of the population.

The problem of bias due to non-response in random samples studies is well-known. It is here further accentuated by the declining proportions of response over time, a wellknown phenomenon from the last fifty years. ${ }^{[51]}$ In previous NordChild studies the distribution of some key variables in children and families have been compared to the appropriate general population. No significant differences between respondents and non-respondents in terms of age and gender were found, but families with a low education, working class families and single-parent families were over-represented among non-respondents in the 1984 and 1996 surveys. ${ }^{[7]}$ In 2011 there were no statistically significant differences in the distribution of background variables among responders and non-responders, with the exception of a low proportion of foreign-born parents among the non-respondents. ${ }^{[52]}$
For the present study a number of key variables have been analyzed more in-depth for time trends. An example is the trends for individual child age years, 13,14 , etc. No example of serious confounding due to the increasing proportions of non-response has been found.

\subsection{Implications for health policies}

We hope that this study will contribute to the actual debates about the determinants of children's health and well-being in affluent countries. In spite of the families' growing economy and improved standard of living, there is a harsh climate in society, with stress, dissatisfaction, bullying and mental health problems. Health policy strategies should aim at making participation in collaborative activities attractive to children and their families. It is also important to strengthen children's social and emotional competence. There are programmes such as PATHS ${ }^{[53]}$ which can be used both for children who have developed mental health problems but also on children in general in school classes in order to promote their health and prevent disease. Another way to strengthen school children's health is to assign enough resources to school health service and educate the health care staff in using cognitive behavioral therapy so that they can support children with problems.

\section{REFERENCES}

[1] Lindström B. On the Quality of Life of Children in the Nordic countries. Theory and Praxis. Gothenburg: Nordic School of Public Health; 1984. 1: 153 p.

[2] Köhler L. Children with and without disabilities in the Nordic countries. A Nordic project. Scand J Soc Med. 1993 Sept; 21(3): 146-9. http://dx.doi.org/10.1177/140349489302100302

[3] Berntsson LT. Health and well-being of children in the five Nordic countries in 1984 and 1996. Gothenburg: Nordic School of Public Health; 2000. 1-109 p.

[4] Berntsson LT, Köhler L. Long-term illness and psychosomatic complaints in the Nordic countries in 1984 and 1996, Comparison between 1984 and 1996. Eur J Public Health. 2001a; 11: 35-42. PMID:11276569. http://dx.doi.org/10.1093/eurpub/11.1 .35

[5] Berntsson LT, Köhler L. Quality of life among children aged 217 years in the five Nordic countries, Comparison between 1984 and 1996. Eur J Public Health. 2001b; 11: 437-5. PMID:11766487. http://dx.doi.org/10.1093/eurpub/11.4.437

[6] Grøholt EK, Stigum H, Nordhagen R, et al. Health service utilization in the Nordic countries in 1996: Influence of socio-economic factors among children with and without chronic health conditions. Eur J Public Health. 2003 Mar; 13(1): 30-7. PMID:12678311. http://dx.doi.org/10.1093/eurpub/13.1.30

[7] Berntsson LT, Köhler L, Vuille JC. Health, economy and social capital in Nordic children and their families: a comparison between 1984, 1996 and 2011. Child: Care, Health and development. 2006;
32(4): 441-451. PMID:16784500. http://dx.doi.org/10.1111 $/ j .1365-2214.2006 .00629 . x$

[8] Berntsson LT, Ringsberg KC. Health and relationships with leisure time activities in Swedish children aged 2-17 years. Scand J Caring Sci. 2014 Sep; 28(3): 552-63.

[9] Berntsson LT, Ringsberg KC. Swedish parents' activities together with their children and children's health: a study of children aged 2-17 years. Scand J Public Health. 2014 Nov; $42(15$ suppl): 41-51. http://dx.doi.org/10.1177/1403494814544901

[10] Ekman-Joelsson BM, Berntsson LT, Sunnegårdh J. Quality of Life in children with pulmonary atresia and intact ventricular septum. Cardiol Young. 2004 Dec; 14(6): 615-21. PMID:15679997. http: //dx.doi.org/10.1017/S1047951104006067

[11] Bratt EL, Ostman-Smith I, Axelsson A, et al. Quality of Life in asymptomatic children and adolescents before and after diagnosis of Hypertophic cardiomyopathy through family screening. J Clin Nurs. 2013 Jan; 22(1-2): 211-21.

[12] Coleman JS. Social Capital in creation of Human Capital. Am J Sociol. 1988; 94: 95-120. http://dx.doi .org/10.1086/228943

[13] Putnam RD, Leonardi R, Nanetti RY. Making Democracy Work: Civic Traditions in Modern Italy. Princeton, NJ, USA: Princeton University Press; 1993.

[14] Weyers S, Dragano N, Richter M, et al. How does socioeconomic position link to health behavior? Sociological pathways and perspectives for health promotion. Global Health Promot. 2010; 17(2): 25-33.

Published by Sciedu Press 
[15] Petrou S, Kupek E. Social capital and its relationships with measures of health status: evidence from the Health Survey for England 2003. Health Econ. 2008 Jan; 17: 127-143. PMID:17516583. http://dx.doi.org/10.1002/hec. 1242

[16] Dunt D, Hage B, Kelaher M. The impact of social and cultural variables of parental rating of child health. Health Promot Int. 2011 Sep; 26(3): 290-301.

[17] De Silva MJ, Huttly SR, Harpham T, et al. Social capital and mental health: a comparative analysis of four low income countries. Soc Sci Med. 2007 Jan; 64(1): 5-20. PMID:17045716. http: //dx.doi.org/10.1016/j.socscimed.2006.08.044

[18] Marmot M. Status Syndrome: How your Social Standing Directly Affects Your Health and Life Expectancy. 2004.

[19] Marmot M. Social determinants and adolescents health. Int J Public Health. 2009; 54: 125-137. http://dx.doi.org/10.1093/ger ona/glp078

[20] Viner RM, Ozer EM, Denny S, et al. Adolescense and the social determinants of Health. Lancet. 2012 Apr 28; 379(9826): 1641-52. http://dx.doi.org/10.1016/S0140-6736(12)60149-4

[21] Kruk KE. Parental income and the dynamics of health inequality in early childhood-evidence from the UK. Health Econ. 2013 Oct; 22(10): 1199-214.

[22] Diener E, Seligman MEP. Beyond money. Toward an economic wellbeing. Psychological Science in the Public Interest. 2004; 5: 1-31. PMID:26158992. http://dx.doi.org/10.1111/j.0963-7214. 2004.00501001.x

[23] Gupta RP, de Wit ML, McKeown D. The impact of Poverty on the current and future health status of children. Paediatr Child Health. 2007 Oct; 12(8): 667-672. PMID:19030444.

[24] Abel T. Cultural capital and social inequality in health. J Epidemiol Community Health. 2008 Jul; 62(7): e13. PMID:18572429. http://dx.doi.org/10.1136/jech.2007.066159

[25] Abel T, Fuhr DC, Bisegger C, et al. Money is not enough: Exploring the impact of social and cultural resources on youth health. Scand J Public Health. 2011 Mar; 39(6 Suppl): 57-61. http: //dx.doi.org/10.1007/s00038-011-0263-7

[26] Calvo R, Zheng Y, Kumar S, et al. Well-Being and Social Capital on Planet Earth: Cross-National Evidence from 142 Countries. PLoS One. 2012; 7(8): e42793. http: //dx.doi.org/10.1371/journ al. pone. 0042793

[27] Abel T, Frohlich KL. Capitals and capabilities: linking structure and agency to reduce health inequalities. Soc Sci Med. 2012; 74(2): 236-244. http://dx.doi.org/10.1177/1403494810378924

[28] Alfvén G. One hundred cases of recurrent abdominal pain in children: diagnostic procedures and criteria for a psychosomatic diagnosis. Acta Paediatr. 2003; 92: 43-49. PMID:12650298. http: //dx.doi.org/10.1111/j.1651-2227.2003.tb00467.x

[29] Grøholt EK, Stigum H, Nordhagen R, et al. Children with chronic health conditions in the Nordic countries in 1996 - influence of socioeconomic factors. Ambul Child Health. 2001; 7: 177-189. http://dx.doi.org/10.1046/j.1467-0658.2001.00129.x

[30] Kimberg B, Sandell R, Bremberg S. Social and emotional training in Swedish schools for the promotion of mental health: an effectiveness study of 5 years of intervention. Health Educ Res. 2008 Dec; 23(6): 931-40. http://dx.doi.org/10.1093/heapro/dam046

[31] SCB (1982). Swedish Socioeconomic Classification, Reports on statistical coordination 1982. Statistics Sweden: Örebro-Sweden; 1982.

[32] Köhler L. Apples and oranges or fruitsallad? On the use of indicators and index. In: Report from the RICHE Project; 2012.

[33] Wilkinson R, Pickett K. The Spirit Level. Why more equal societies almost always do better. London: Allen Lane; 2009.
[34] Bremberg S. Social health inequalities in Swedish children and adolescents - a systematic review, secondedition. Stockholm A: Swedish National Institute of Public Health; 2011. 11 p.

[35] Marmot M, Allen J, Bell R, et al. On behalf of the Consortium for the European Review of Social Determinants and the Health Divide. WHO European Review of Social Determinants and the Health Divide. Lancet. 2012; 380: 1011-29. http://dx.doi.org/10.1016 /S0140-6736 (12)61228-8

[36] Mackenbach JP. The persistence of health inequalities in modern welfare states: The explanation of a paradox. Soc Sci Med. 2012 Aug; 75(4): 761-769. http://dx.doi.org/10.1016/j.socsc imed.2012.02.031

[37] Currie C, Zanotti C, Morgan A, et al. Social determinants of health and well-being among young people. Health Behaviour in School-aged Children (HBSC) study: international report from the 2009/2010 survey. Copenhagen, WHO Regional Office for Europe. 2012.

[38] Klinger DA, Freeman JF, Bilz L, et al. Cross-national trends in perceived school pressure by gender and age from 1994 to 2010. Eur Public Health. 2015; 25(2 supplement): 51-56. PMID:25805788. http://dx.doi.org/10.1093/eurpub/ckv027

[39] Health of children and young people. Knowledge base for the Public Health Policy Report 2010. Swedish National Institute of Public Health, FHI, Stockholm; 2010.

[40] Hjern A. Health in Sweden: The National Public Health Report. Scand J Public Health. 2012; 40(9 Suppl): 23-41. http: //dx . doi .org/10.1177/1403494812459610

[41] Bremberg S. Mental disorders in young people in the Nordic countries: trends and measures. Stockholm: Swedish institute of Public Health; 2014.

[42] Lereya ST, Copeland WE, Costello EJ, et al. Adult mental health consequences of peer bullying and maltreatment in childhood: two cohorts in two countries. Lancet 2015: Psychiatry. 2015. http//dx .doi .org. 10.1016/52215-0366 (15-00165-0

[43] Gunnarsdottir H, Povlsen L, Ringsberg KC. Health, Lifestyles of preschool children in Nordic countries: parent perspectives. Health Promot Int. 2013. http://dx.doi.org/10.1093/heapro/dat0 79

[44] Nordic Statistical Yearbook. Copenhagen: Nordisk Ministerråd; 2014.

[45] Berntsson LT, Gustavsson JE. Determinants of psychosomatic complaints in Swedish schoolchildren aged seven to twelve years. Scan J Public Health. 2000; 28: 283-93. http://dx.doi.org/10.1080 /14034940050500537

[46] Jago R, Brockman R, Fox KR, et al. Friendship groups and physical activity: qualitative findings on how physical activity is initiated and maintained among 10-11 year old children. Int J Behav Nutr Phys Act. 2009 Jan 12; 6: 4. http://dx.doi.org/10.1186/1479-5 868-6-4

[47] Petersen S, Bergström E, Cederblad M, et al. Mental health of children and adolescents in Sweden 1945-2009. A systematic review of the literature. Stockholm: Royal Swedish Academy of Sciences, Health Committee; 2010.

[48] Torsheim T, Ravens-Sieberer U, Hetland J, et al. Cross-national variation of gender differences in adolescent subjective health in Europe and North America. Soc Sci Med. 2006; 62: 815-827. PMID:16098649. http://dx.doi.org/10.1016/j.socscimed .2005 .06 .047

[49] Eriksson U, Hochwälder J, Carlsund Å, et al. Health outcomes among Swedish children: the role of social capital in the family, school and neighborhood. Acta Paediatr. 2012 May; 101(5): 513-517. 
[50] Cattaneo A, Cogoy L, Macaluso A, et al. Child Health in the European Union. Institute for Maternal and Child Health IRCCS Burlo Garofolo, Trieste. European Commission. 2012.

[51] Schoeni RF, Stafford F, McGonagle KA, et al. Response rates in national panel surveys. The Annals of the American Academy of Political and Social Science. 2013: 645; 60-87. PMID:23358122. http://dx.doi.org/10.1177/0002716212456363
[52] Bergstrom M, Fransson E, Hjern A, et al. Mental health in Swedish children living in joint physical custody and their parents' life satisfaction: A cross-sectional study. Scandinavian Journal of Psychology. 2014. http://dx.doi.org/10.1111/sjop. 12148

[53] Greenberg MT. Promoting resilience in children and youth: preventive interventions and their interface with neuroscience. Ann NY Acad Sci. 2006; 1094: 139-150. PMID:17347347. http://dx. doi .org/10.1196/annals.1376.013 